\title{
Economic Genocide under International Law
}

\section{Morris, Patrick-Sean}

2018-03-04

Morris , P-S 2018 , ' Economic Genocide under International Law ' , Journal of Criminal Law , vol. 82 , no. 1 , pp. 18-34 . https://doi.org/10.1177/0022018317749698

http://hdl.handle.net/10138/324777

https://doi.org/10.1177/0022018317749698

cc_by_nc_nd

acceptedVersion

Downloaded from Helda, University of Helsinki institutional repository.

This is an electronic reprint of the original article.

This reprint may differ from the original in pagination and typographic detail.

Please cite the original version. 


\section{Economic genocide under international law}

\section{P. Sean Morris ${ }^{\star}$}

\section{Abstract}

The status of genocide in international law is well developed and forms part of customary international law and also treaty law. International tribunals such as the International Criminal Court (ICC) and specialised chambers such as the International Criminal Tribunal of the Former Yugoslavia (ICTY) and the International Criminal Tribunal for Rwanda (ICTR) have addressed and made a number of convictions regarding genocide. This relative success in the international criminal justice system regarding genocide has given the appearance that perpetrators responsible for genocide will be brought to justice. Yet, there is a fundamental crack in international criminal law with regards to genocide as a crime and how to bring perpetrators to justice. That crack, is essentially, the narrow scope and definition of genocide, and also, how to demonstrate that perpetrators had the intention of committing genocide. I contend in this paper that the scope of genocide should be extended to include economic genocide and argue that spill over intent of aiders and abettors of genocide requires more clear and coherent rules to include economic genocide as part of how the crime of genocide is assess in international law. The paper first presents and discuss the notion of genocide taking into consideration the Genocide Convention (1948) and then discuss the status of article 2(c) of the Convention to define economic genocide. The paper then posit that calculated economic measures that affects the conditions of life of peoples involves intent and that that intention has a spill over effect.

\section{Introduction}

The notion of economic genocide is not generally associated with how contemporary international law is being interpreted or applied. Yet, apart from the various questions that plagues international law, such as ethnic cleansing, mass murder, apartheid, holocaust, human trafficking, reparations for slavery, a debate from the other side of the coin is missing from these narratives. A few works have made some inroads in developing the narrative on the economic aspects of genocide. ${ }^{1}$ This debate is welcome, but it is a debate that is largely missing from the legal literature, and, therefore, a contextual analysis of economic genocide in light of the Genocide Convention is required. ${ }^{2}$

\footnotetext{
- Faculty of Law, University of Helsinki, Sean.Morris@helsinki.fi

${ }^{1}$ See Charles Anderton and Jurgen Brauer (eds), Economic Aspects of Genocides, Other Mass Atrocities, and their Prevention (OUP, 2016); Donald Bloxham and Dirk Moses, The Oxford Handbook of Genocide Studies (OUP, 2010); Garry Leech, Capitalism: A Structural Genocide (Zed Books, 2012); Nafeez Ahmed, 'Structural Violence as a Form of Genocide - The Impact of the International Economic Order' (2007) 5 Entelequia: Revista Interdisciplinar 3 - 41. ${ }^{2}$ Convention on the Prevention and Punishment of the Crime of Genocide, 9 December 1948, 78 UNTS 277.
} 
Although the Genocide Convention remains an important step in recognising genocide as a crime in international law - the Convention does not contain, stricto sensu, any reference to economic genocide. The main provision of the Convention that defines genocide is article 2. According to this provision genocide encompass killing, serious bodily or mental harm, conditions of life that may bring about destruction, measures to prevent birth and forcibly transfer of children within a group in a society. ${ }^{3}$ The part of article 2 that can best be interpreted as closely connected to economic genocide is the third clause, that defines genocide to include deliberately inflicting on the group conditions of life calculated to bring about its physical destruction in whole or in part. It is this provision that has the closest bearings to define and infer economic genocide as crime in international law because it is very broad and can potentially be interpreted as covering a wide range of issues.

An argument can be made that article 2(c) of the Genocide Convention represents the various compromises during the preparatory stages. This is so, because the documentary evidence of the various meetings of the Convention reveals that Latin American countries and Saudia Arabia lobbied for economic genocide to be included in the Convention, ${ }^{4}$ but their proposals never made it into the Convention (discussed below). Thus, apart from meeting a cold death during the negotiations of the Genocide Convention, subsequent developments reveal that economic genocide occurred on numerous occasions either in conflict zones or economic policies were precursors to conflicts where genocide occurred. ${ }^{5}$ So, why has economic genocide been side-lined, or excluded from the narrative in contemporary international law? Is a debate on the concept of economic genocide counter-productive to what is set in stone in the Genocide Convention, or, given that since the end of World War Two, the narrative in international law has been mostly conducted by Western academics who failed to see how economic policies and the question of Western investments in resource riched countries are linked to genocide?

\footnotetext{
${ }^{3}$ Ibid, art 2(a) - (e).

${ }^{4}$ A/C.6/149, 29 September 1947, Sixth Committee, Draft Convention on Genocide: Draft Resolution proposed by the Delegation of Venezuela, further discussed on 6 October 1947.

${ }^{5}$ Eg, Marie Besancon, 'Relative Resources: Inequality in Ethnic Wars, Revolutions, and Genocides' (2005) 42 Journal of Genocide Research $393-415$.
} 
The contemporary international legal order has fundamentally changed in the last seven decades, and even more so, in the last two decades, where the emphasis of international relations is primarily on the economic legal relations of states. This new emphasis is also a challenge to the old system of international law where various aspects of economic relations defines how nation states interact. The end of the ColdWar has given rise to a new stream of academic scholarship in international law that focuses on human rights, trade, globalisation and more recently security law. But that stream of literature is also tied to the interests of Western States and channel through their academic institutions.

The silent voices in international law from the South (and where genocide is likely to occur) became increasingly active in the post-Cold War scholarship of international law. But it was at a cost. The forgotten voices from the South in international law became part of the contemporary direction and scholarship in international providing that they endorse (a) the traditional interests such as trade and human rights of the West, and (b) their states are party to the International Criminal Court. In this regard, the guardians of the old international legal order must now compete within the crowded field of international law that lends new voices and scholarship to the living element of international law. And, it is because of the rise of the living element of international law, that it is possible to "revisit" the notion of economic genocide and its place in the international legal order.

One drawback of the new international legal order that emerged in the last few decades because of globalisation and the economic legal relations of states, is that, given that the rules have been drawn up by the old guardians of international law whether as negotiators, academics, through advocacy or state actions, the new rules also favour the economic interests of the traditional powerful states in international relations. As a result of this, economic actors in powerful states such as multinational corporations, defence industries, trading associations engages their governments to shape international economic relations and investments to their advantage. For instance, most bilateral investment treaties contain clauses for private arbitration - often at the detriment of the host states. But the broader implication of the rules favouring powerful economic interests is that those same rules, tacitly or inadvertently, lead to economic 
disadvantages in states that are full of natural resources but lacks sufficient technological methods for the exploitation of those resources.

As such, the great economic disparity among states, the reliance on international investments and global markets, and the system of weak international law that plays to the advantage of the more economic superior states creates a pattern that promotes economic genocide in states in states that where there are huge inequalities among the various classes of peoples and are dependent on the global markets including the disparities in the international economic system.

\section{Genocide as a crime in contemporary international law}

After the events of World War Two and the subsequent war trials for various crimes against humanity, one of the new legal remedies to prevent similar atrocities in the future was the 1948 Genocide Convention creating a new form of crime - genocide. The main purpose of the Genocide Convention is to punish genocide as crime under international law as its preamble pronounces, and, where such crime is contrary to the spirit and aims of the civilised world and the Charter of the United Nations (UN). As such, from 1946 - 1948 serious efforts were undertaken at the UN for the adoption of the Genocide Convention. The Economic and Social Council (ECOSOC), the UN body whose task it was initially to carry out preliminary studies and the drafting of the Genocide Convention eventually enlisted the UN Secretariat for expertise on international law. However, when the Draft Convention was circulated - it never gained enough support, and an Ad hoc Committee produced a Second Draft Convention that was eventually adopted by the United Nations General Assembly (UNGA) in $1948 .^{6}$

Shortly after it came into force the Genocide Convention was the subject of an Advisory Opinion from the International Court of Justice (ICJ) in 1951 in which the ICJ declared that in a convention of this type one

\footnotetext{
${ }^{6}$ William Schabas, Genocide in International Law: The Crime of Crimes ( $2^{\text {nd }}$ edition, CUP, 2009) chapter 2; see also, Lawrence LeBlanc, 'The ICJ, The Genocide Convention, and the United States' (1987) 6 Wisconsin International Law Journal 43, 48.
} 
cannot speak of individual advantages or disadvantages to States, or of the maintenance of a perfect contractual balance between rights and duties. ${ }^{7}$ This first foray of the ICJ into the Genocide Convention set out what would become an uneasy relationship over the decades. And by 1996, the ICJ had again been called upon to examine parameters of the Genocide Convention. In Bosnia v Yugos/avia $(1996)^{8}$ was asked to determine if states could become a party to the Genocide Convention as a result of succession. The ICJ affirmed and noted that it had jurisdiction 'to give effect to the Genocide Convention'. ${ }^{9}$ Since then, the Genocide Convention has been used to set up tribunals for the prosecution of crimes in places such as Rwanda and the Former Yugoslavia.

The Genocide Convention sets out a broad concept of Genocide; article 2 of the Genocide Convention defines genocide and that definition largely incorporates three elements of genocide. The first is the targeting special or protected groups that are based on race, religion and ethnicity. The criminal act (actus reus) where the actual killing of members of the groups identified in the first element, or causing various types of harms such as bodily or mental, and affecting their conditions of life is the second element of a genocide. The third element of a genocide is the criminal intent (mens rea) to commit genocide. It is this latter provision which has proven to be the most controversial of the Genocide Convention, as it has become notoriously difficult to demonstrate criminal intent to commit genocide. Nevertheless, these elements of the Genocide Convention have been interpreted in various international tribunals in cases such as Prosecutor v Jean-Paul Akayesu ${ }^{10}$ at the International Criminal Tribunal for Rwanda (ICTR), ${ }^{11}$ and Prosecutor $v$ Krstic $^{12}$ at the International Criminal Tribunal for the Former Yugoslavia (ICTY). Moreover,

\footnotetext{
${ }^{7}$ Reservations to the Convention on the Prevention and Punishment of the Crime of Genocide, [1951] ICJ Reports 15, 23.

${ }^{8}$ Application of the Convention on the Prevention and Punishment of the Crime of Genocide, Preliminary Objections, Judgment, [1996] ICJ Reports, p. 595.

${ }^{9}$ lbid, para. 34.

${ }^{10}$ Prosecutor v Jean-Paul Akayesu, Case No. ICTR-96-4-T, 2 September 1998.

${ }^{11}$ The International Criminal Tribunal for Rwanda (ICTR) was set up by the UN in 1994 for the prosecution of persons responsible for genocide and other serious violations of international humanitarian law during the Rwandan genocide in 1994, Security Council Resolution 955 (1994) (Establishment of the International Criminal Tribunal for Rwanda), UN Doc. S/RES/955 of 8 November 1994. Article 2(2)of the Statute of the ICTR similarly defines genocide as in the Genocide Convention.

12 Prosecutor v Radislav Krstic, Case No. IT-98-33-A, 19 April 2004.
} 
economic cases such as Oil Platforms ${ }^{13}$ at the ICJ often incorporates the necessity of the Genocide

Convention.

The actual concept and meaning of genocide as set out in article 2 provides:

'In the present Convention, genocide means any of the following acts committed with intent to destroy, in whole or in part, a national, ethnical, racial or religious group, as such:

(a) Killing members of the group;

(b) Causing serious bodily or mental harm to members of the group;

(c) Deliberately inflicting on the group conditions of life calculated to bring about its physical destruction in whole or in part;

(d) Imposing measures intended to prevent births within the group;

(e) Forcibly transferring children of the group to another group.'

This definition of genocide in article 2 of the Genocide Convention shows that what constitute genocide clearly targets a traditional understanding of crime that involves a recourse to a criminal justice system. The ICJ in Bosnia v Herzegovina confirmed a related definition of genocide by noting that, genocide, as a crime under international law includes 'a denial of the right of existence of entire human groups. ${ }^{14}$ However, the ICJ was merely reasserting the merits of 1951 Reservations Opinion ${ }^{15}$ by explaining that genocide was also contrary to moral law and that mankind should be liberated from 'such an odious scourge. ${ }^{16}$ But, by addressing genocide as an odious scourge that denies rights to groups of people was one way for the ICJ to contribute to the definition of genocide and provide a moral lead for the existence of genocide under international law. Therefore, it is not surprising that the constitutions of the various criminal tribunals that were set up after the Genocide Convention revert to the same definition of genocide in article 2 of the Convention, ${ }^{17}$ and the definition similarly echoed by the ICJ.

Given that the Convention emerged out of the post-war era, arguably, the definition of genocide, as set out in article 2, in some ways describe similar atrocities committed against the Jews and other ethnic minorities

\footnotetext{
${ }^{13}$ Case Concerning Oil Platforms (Islamic Republic of Iran v United States of America) [1996], IC Reports 803, 12 December 1996 (dismissing a violation of customary international law claims, including the Genocide Convention, Preliminary Objection submitted by the United States of America, 16 December 1993, note 95).

${ }^{14}$ Application of the Convention on the Prevention and Punishment of the Crime of Genocide, Preliminary Objections, Judgment, [1996] ICJ Reports, p. 595. para. 31.

15 Ibid.

16 Ibid.

${ }^{17}$ For example, Rome Statute of the International Criminal Court, 2187 UNTS 3, 17 July 1998, art 6.
} 
during the war. The Nuremburg Trials for instance, took place, in parallel with the negotiations for the Genocide Convention, and, therefore, the Nuremberg judgements affirmed the existence of the concept of genocide in international law. ${ }^{18}$ The Nurnberg Trials did not render a specific judgment that could be linked to the concept of genocide. But such a development, would be fifty years later after the Nurnberg Trials, when the Genocide Convention was used to convict an African, who was a public official in Rwanda, and, had the esteemed honour in international criminal justice to be convicted of a crime of genocide. ${ }^{19}$

As one of the first international criminal tribunal that was set up to specifically handle crimes of genocide the International Criminal Tribunal for Rwanda (ICTR) in its Akayesu judgment held that Jean-Paul Akayesu, a former Rwandan bureaucrat, engaged in culpable acts that were systemically directed at a group of people, and, therefore it was possible for the Chamber 'to deduce the genocidal intent' of a particular act. ${ }^{20}$ The mandate of the ICTR as set out in UN Resolution 955 via article 1 of the Statute is to 'prosecute persons responsible for serious violations of international humanitarian law'. Given that the ICTR's mandate involves international humanitarian laws, then the ICTR could not be restricted only to genocide. As such, article 3 provides for punishment of crimes against humanity. The inclusion of crimes against humanity in the ICTR statute raises the question as to the distinction between genocide and crimes against humanity in the broader realm of international law. ${ }^{21}$ But that argument, perhaps, lie in an academic rivalry between two preeminent international lawyers in the post-war era, ${ }^{22}$ and their legacies, have shaped a dual and competing approach to the make-up of crime in international law.

A great feat of the Genocide Convention is that it codified practices in customary law relating to crimes. For states that are signatory to the Genocide Convention, they are able to resort to a modern and universal

\footnotetext{
${ }^{18}$ Trials of War Criminals Before the Nuernberg Military Tribunals under Control Council Law No. 10, Nuernberg, October 1946 - April 1949, Vol. 3, 983, noting that 'genocide is a crime under international law' and the crime of genocide include the destruction of racial, religious and other groups.

${ }^{19}$ Akayesu (n 10).

${ }^{20}$ Ibid, para 523.

${ }^{21}$ See eg, ILC, Draft Code of Offences Against the Peace and Security of Mankind, Vol. II Yearbook of the International Law commission 249 (1950); Patricia Wald, 'Genocide and Crimes Against Humanity' (2007) 6 Washington University Global Studies Law Review 621 - 633.

${ }^{22} \mathrm{Eg}$, Ana Vrdoljak, 'Human Rights and Genocide: The Work of Lauterpacht and Lemkin in Modern International Law' (2009) 20 EJIL $1163-1194$.
} 
system of punishment. But states that are not members of the Genocide Convention can still exercise customary international law practices for genocidal crimes. Off course, state parties to the Convention are at an advantage, because they are able to 'define and develop the rules of customary law in order to secure certain practical results. ${ }^{23}$ But there lies a problem also. States that are party to the Genocide Convention are susceptible to criticism that they use the Genocide Convention to prosecute and imprison the weak or members of certain ethnic groups.

The ICTR and the ICTY have had a high success rate in their indictment and completed cases. ${ }^{24}$ While the comparison between the ICTR and the ICTY is neutral in that they had specific purposes for certain geographic regions, the situation is not the same for the ICC, as most of those it indicted or charged for genocide is unbalanced in that the defendants are mostly Africans. ${ }^{25}$ This has raised many questions, but that debate is for another time. Suffice to say that even though the first person to be convicted of genocide was an African, Jean Paul Akayesu, in the ICTR, I believe that later convictions in the ICTY were, in part, a face saving moral boost of the Genocide Convention given that the genocide committed during the Balkans War such as the Srebrenica massacre was an odious scourge contrary to the spirit and aims of the civilised European world. The success of the ICTR and the ICTY is nevertheless a bright spark in international criminal justice, and furthermore, as an international legal instrument to punish the crime of genocide, ${ }^{26}$ there is nothing inherently wrong with the Genocide Convention in that regard.

The existence of an international legal mechanism to systematically punish abhorrent crimes in international law lends some level of trust both for victims and the international judicial process. But the accolades for the Genocide Convention ends there. Soon after the coming into force of the Genocide

\footnotetext{
${ }^{23}$ Hirad Abtahi and Philippa Webb, The Genocide Convention - The Travaux Preparatoires (Martinus Nijhoff Publishers, 2008) 674.

${ }^{24}$ The ICTR indicted 93 individuals for genocide and other serious violations of international humanitarian law committed in 1994. Of this number the ICTR concluded proceedings for 95 accused including 5 transferred to other jurisdictions. At the ICTY 161 individuals were indicted and 83 were sentenced, and 19 acquitted, 13 transferred and some 37 proceedings were terminated or had their indictments withdrawn.

${ }^{25}$ The ICC is currently investigating alleged crimes committed in the Democratic Republic of the Congo; Mali; Sudan (Darfur); Uganda; Central African Republic; Kenya; Libya; Ivory Coast and the former Soviet Republic of Georgia.

${ }^{26}$ See also, Robert Kolb, 'The Jurisprudence of the Yugoslav and Rwandan Criminal Tribunals on their Jurisdiction and on International Crimes (2004 - 2013)' (2014) 84 British Yearbook of International Law 131 - 186.
} 
Convention, and other international instruments covering human rights and conflicts, the aims and objectives of those instruments, including the Genocide were effectively frozen during the cold war. As a result, no tribunals under the Genocide Convention were established during the cold war. The only form of justice in the international judicial system during the cold war was for trade and economic disputes mostly among Western liberal states through arbitration or specialised economic tribunals such as the Iran-Claims Commissions.

Genocide as a concept lost relevance during the cold war, and economic disparities among socialist leaning and capitalists leaning states were of a high proportion. What began to gradually emerge, as socialist leaning states began to tilt towards liberalism during the 1980 s and the early 1990 s, was that, the concept of genocide suddenly has a new meaning. However, that meaning was in relation to the huge economic disparities and the aggressive nature of Western capitalist institutions and their hunger for wealth. Even at the end of the cold war and the acceptance of capitalism by former Soviet states such as Russia, the impression of capitalism by most Russians was that it represents a form of economic genocide. ${ }^{27}$ But the notion of economic genocide was not only a concern for Russians. Smaller states in Africa and Asia that fed the larger liberal states with natural resources during the cold war were beginning to cry foul and that investments and uneven trade rules resulted in a form of economic genocide, or at least contributes to economic genocide. So, the relevant question is, in the light of the concept of genocide, as articulated in the Genocide Convention, is there such a thing as economic genocide, and if so, how does it bare any relation to the tests for genocide - the intention to commit genocide? Does the existence of oil in Darfur, natural resources in Myanmar, Coffee in Rwanda, or diamond in the Democratic Republic of the Congo contributes to how genocide should be conceived from an economic perspective? Should the actions of transnational corporations operating in conflict zones contribute to how economic genocide is understood?

\footnotetext{
${ }^{27}$ See Celestine Bohlen, 'Yeltsin Deputy Calls Reforms 'Economic Genocide”, 9 February 1992, New York Times.
} 


\section{Economic genocide and the deliberate inflicting on the group conditions of life calculated to bring about its physical destruction}

Notwithstanding the broader legal doctrines of genocide as discussed in the previous section - a linkage must be made between genocide and its root economic causes. While, there have been a strong and fragmenting cadre of literature that attempts to create a narrative on the "rights" to economic resources in international law, ${ }^{28}$ e.g., the right to food, or the right to water - the shortcomings in the literature are that they do not create a link to genocide as defined in the Convention. In the Krstic judgment, at least, the tribunal raised the spectre of economic woes as a link to genocide, albeit, in a skeletal manner: 'economic woes and the end of communist rule set the stage for rising nationalism and ethnic friction.. ${ }^{29}$ To create or link genocide to economic woes, and hence, its root causes, a few factors should be looked at. These factors emanate from contemporary conflicts where land and natural resources are inherently valuable to various actors at the global, the corporate economic system and the domestic actors. These factors are complex and interwoven but their desired goals of economic value and output connects them to control, power and genocide.

In conflict zones such as the Rwandan genocide, it has been mooted, that financial austerity was the root cause of the conflict. ${ }^{30}$ Choussudovsky also and others have also argued that the collapse of the coffee market in the late 1980 s and early 1990 s and the economic reforms demanded by multilateral agencies such as the IMF contributed to the Rwandan genocide. ${ }^{31}$ This claim, from an economic perspective, however, should not be dismissed, as there are evidence that financial austerity often result in the collapse of nation states, and in part, due to deliberate target of their economic institutions. ${ }^{32}$ Furthermore, the

\footnotetext{
${ }^{28}$ Sabine Scheuring, 'Is there a right to water in international law? (2009) 15 UCL Jurisprudence Review 147 - 171.

${ }^{29}$ Prosecutor v Radislav Krstic, Case No. IT-98-33T, 2 August 2001, para. 9

30 Michel Chossudovsky, 'Economic Genocide in Rwanda' (1996) 31 Economic and Political Weekly 938 - 941;

'Human Security and Economic Genocide in Rwanda', in Caroline Thomas and Peter Wilkin (eds), Globalization, Human Security, and the African Experience (Lynne Rienner Publishers, 1999).

31 Ibid; see also, Issa Kamola, 'The Global Coffee Economy and the Production of Genocide in Rwanda' (2007) 28 Third World Quarterly $571-592$.

32 See also, William Schabas, Genocide in International Law: The Crime of Crimes (CUP, 2000) 152, noting that economic genocide also includes the targeting of a 'group's economic institutions and its source of livelihood', and
} 
coffee industry has been vital to the Rwandan economic up to the late 1980s but the collapse of the coffee cartel and the fight for control over coffee production in Rwanda were factors that played a part in the subsequent genocide.

Writing in 1992 Egon Zizmond was blunt about the destruction that ravished the former Yugoslavia.

According to Zizmond two factors were equally responsible: (1) the make-up of the Yugoslav constitution of 1974 and (2) economic policies. ${ }^{33}$ This claim by Zizmond has not gotten full treatment in the legal literature, especially connecting it to the crimes of genocide in the former Yugoslav Republic. I will attempt to do so later in this section, to demonstrate that deliberate economic measures inflicted destruction, and therefore constituted economic genocide and fell within the remit of the Genocide Convention.

As shown above, the idea of economic genocide during the preparatory stage of the Genocide Convention was widely supported by a few states. ${ }^{34}$ The supporters of economic genocide however, were states, that were, by today's standards "underdeveloped" or "third-world" in the 1940s. The Venezuelan initiative for economic genocide to be included in the Draft Convention was not the only such proposal. Another proposal from Saudia Arabia in the Draft Convention included genocide to encompass 'economic structure. ${ }^{35}$ The Latin American initiative for economic genocide to be included in the Convention appeared after the Saudi Draft Convention of 1946. The Venezuelan initiative however, went beyond the notion of "economic structure" that the Saudi Draft contained. The Latin Americans specifically proposed for a supplemental provision covering economic genocide - which was defined as: 'genocide committed by means of the economic destruction of whole groups of people. ${ }^{36}$ These initiatives ultimately failed. However, the philosophical credit to include economic genocide as part of the crimes of crimes in the

also, citing Raphael Lemkin, Axis Rule in Occupied Europe: Laws of Occupation, Analysis of Government, Proposals for Redress (Washington, 1944) 145.

${ }^{33}$ Egon Zizmond, 'The Collapse of the Yugoslav Economy' (1992) 44 Soviet Studies 101 - 112: 'On the economic front, conflicts occurred because of the economic system and the economic policy of the federal government. Conflicting economic interests ... caused a collapse in the unity of the Yugoslav market,' 110.

${ }^{34}$ See (n 4).

${ }^{35}$ Article 1, Draft Genocide Convention, UN Doc.A/C.6/86, cited in Schabas (n 32) 145.

${ }^{36}$ Hirad Abtahi and Philippa Webb, The Genocide Convention - The Travaux Preparatoires (Martinus Nijhoff Publishers, 2008) 402. 
convention appears to lie with Rafael Lemkin. His argument on the destruction of economic structure as genocide had been widely known. But whatever, the motives of Lemkin for advocating economic structure to be included in how genocide should be defined, contemporary scholars agree that several adverse economic events destroy the economic structure of a society and are akin to genocide. ${ }^{37}$

The closet provision in the adopted Genocide Convention that matched the efforts of the Latin American group during the preparatory stage is paragraph (c) of article 2 . There are four elements in the paragraph that carries the same language and tone and spirit of both the Latin American initiative and the Draft Saudi Convention: (1) "deliberately inflicting", (2) "conditions of life", (3) "calculated", (4) and "physical destruction". This is so, because, this clause of article 2 of the Genocide Convention allows for the widest interpretation. I will use this clause, in particular, the element of "deliberately inflicting" and "calculated conditions of life" to demonstrate that the genocide in Sudan, was a form of economic genocide. States or nations that experience conflicts often go through a series of slow and internal breakdown of civil unrest, so much so, that is normal to refer to those states as failed states, blame religious and ethnic cultural differences, or, they lack civilised norms and the rule of law often presumably exists in Western society. But because of a failure to examine the economic decision-making policies that influence societal breakdown and the emergence of conflicts, then, it is also easy to exclude the conditions that leads to economic genocide.

In Akayesu for instance, the tribunal observed that by blaming deteriorating economic conditions on certain ethnic groups creates favourable conditions for the crime of genocide: ' $[A] t$ the time the Convention on Genocide was being drafted, the Polish delegate observed that it was sufficient to play skilfully on mob psychology by casting suspicion on certain groups, by insinuating that they were responsible for economic or other difficulties in order to create an atmosphere favourable to the perpetration of the crime. ${ }^{\prime 38}$ This

\footnotetext{
${ }^{37}$ See Ndiva Kofele-Kale, The International Law of Responsibility for Economic Crimes: Holding State Officials Individually Liable for Acts of Fraudulent Enrichment (Ashgate, 2006) 12-13 defining economic genocide and proposing a new terminology - patrimonicide. Although a brilliant attempt, such tongue twister will eventually get lost in an already convoluted system where consensus is not mutual regarding the notion of economic genocide. ${ }^{38}$ Akayesu (n 10) para. 557, citing the Summary Records of the Sixth Committee of the General Assembly, 21 September -10 December 1948, Official Records of the General Assembly.
} 
argument by the Akayesu court indicates that (a) when considering the crime of genocide, economic conditions must be considered, especially, if those economic conditions can be used favourably by the perpetrators of genocidal crimes, and (b) that the draftsmen of the Genocide Convention were unhappy that genocidal crimes linked to economic conditions were eventually excluded.

The crime of genocide is ex post, in that, charges are only possible after the evidence that a crime has been committed. In this context, when considering possible economic actions that are in part responsible for genocide then the economic conditions leading up to the crime and present during conflicts where genocide occurs must be examined. Genocide do not take place outside of the context of conflict, and, as such, do deliberate economic measures that leads to destruction complicit or responsible for the crime of genocide?

\section{A. Deliberate economic measures that inflicts destruction}

The first point to consider that can help in constructing the notion of economic genocide is to look at economic measures at the domestic level that inflicts destruction. By addressing economic measures at the domestic level two criticisms can be avoided. The first criticism is that a domestic analysis avoids the need to blame external economic forces, such as austerity measures, the rights and obligations of foreign investors, or the state of global markets for natural resources. Thus, by painting bare the domestic economic conditions satisfies the first criticism. The second criticism to overcome is whether public officials had any economic interests in national economic policies that would exacerbate conflict and hence genocide. The more recent conflict in the Balkans and the ICTY is a suitable example. Both the Former Yugoslavia and Rwanda presents themselves as credible case studies as several public officials from those countries were found guilty of the crime of genocide by international criminal tribunals. Therefore, looking at the economic internal situation prior to the onset of the conflicts that lead to genocide should be able to make a greater connection to the concept of economic genocide. 
Towards the end of the 1970s and in the 1980s the Socialist Federal Republic of Yugoslavia (SFRY) began to experience a severe economic crisis, predominantly as a result of the drying up of western financing of the Yugoslav economy. ${ }^{39}$ Faced with a mounting debt and several restructuring agreements with international lenders such as the International Monetary Fund (IMF) and the Paris Club, the Yugoslav economy from 1982 began a downward spiral and by 1989 economic growth was at 0.6 percent. ${ }^{40}$ As the economic crisis worsened, the constituent republics began a push for secession, as prosperous republics blamed Belgrade for disastrous economic policies that lead to hyperinflation and devaluation. ${ }^{41}$ From the summer of 1991 through the Spring of 1992 the larger republics seceded and precipitated the Balkans war for which the crimes of crimes - genocide was the charge.

Although various studies exists that attempts to explain the collapse of Yugoslavia and subsequently the root cause of the Balkans war on various factors, only a few have made the connection to economic factors and the subsequent conflict. ${ }^{42}$ For instance, Yarashevich and Karneyeva argues that the collapse of Yugoslavia was in part due to 'more complex economic conflicts that built up throughout the post-war period. ${ }^{43}$ Belgrade was the capital of the Federal Republic and the seat of political power. Belgrade was also the capital of the dominant republic Serbia and thus, succeeded the political and economic control of Yugoslavia. So what were the economic policies that Belgrade, and, by and large, Serbia implemented prior to the outbreak of the conflict? Prior to answer that question, a few sentences on the economic causes of conflicts in a broader setting can help to justify an answer.

In countries, or among group of peoples where genocide occurred in the latter part of the twentieth century, the blame can arguably be with top down economic coercion by external forces. Conflicts and war

\footnotetext{
${ }^{39}$ Viachaslau Yarashevich and Yuliya Karneyeva, 'Economic Reasons for the Break-Up of Yugoslavia' (2013) 46 Communist and Post-Communist Studies $263-273$.

40 Ibid, 269.

41 Ibid, 272.

42 Ibid, 273.

43 Ibid, also citing, Egon Zizmond, 'The Collapse of the Yugoslav Economy' (1992) 44 Soviet Studies $101-112$. For a more recent discussion on the economic performance of the former Yugoslavia see, Leonard Kukic, 'Socialist Growth Revisited: Insights from Yugoslavia' June 2015.
} 
arise due to economic deterioration among a group of people or in a nation state. ${ }^{44}$ Stable and prosperous nations that are homogenically identical rarely descend into civil war or any form of internal conflict in the modern era. Even where the wealth gap between the rich and the poor in homogenous states are wide, a system of social laws are in place to protect those at the bottom of the wealth ladder.

The situation is not the same for countries that are ethnically diverse, based on race, religion, culture among other factors and are poor. Eventually, competition over natural resources, ${ }^{45}$ the direction of economic policies and inequalities drives social and economic divisions that leads to conflicts. Conflicts under these circumstances, whether local in origin or due to external coercion creates a war economy. A war economy may lead to increase in production of goods from natural resources or may propel one side in a conflict to control the production and flow of goods from natural resources. This can bring positive and negative consequences for peoples of groups or the fate of an entire country.

During the Rwandan genocide, the prevalence of coffee has been linked to the genocide and 'exclusionary politics' among various ethnic groups. ${ }^{46}$ For the casual observer, the linking of the economic importance of coffee to genocide may seem absurd, but, in reality, different economic groups enjoy different economic resources as a means of livelihood. For Rwanda, coffee was the main means of livelihood and the top earner of foreign exchange. The collapse of the international coffee agreement in $1989^{47}$ only fomented the seeds of genocide from an economic perspective, for a country that was already divided along ethnic groups, language and other factors. Thus, what was primary a product for global markets and locally harvested in Rwanda hastened a genocide from an economic perspective. But more telling was the fact that

\footnotetext{
${ }^{44}$ See generally, Gregory Hess (ed), Guns and Butter: The Economic Causes and Consequences of Conflict (MIT Press, 2009); Ditrih Jung, 'The Political Economy of Modern Wars', in Miroslav Hadzic (ed), The Violent Dissolution of Yugoslavia Causes, dynamics and effects Collection of Papers (Belgrade, 2004).

45 Philippe Le Billon, 'The Political Ecology of War: Natural Resources and Armed Conflicts' (2001) 20 Political Geography $561-584$.

${ }^{46}$ Le Billion, ibid., 568

${ }^{47}$ See also, Kamola (n 31).
} 
the weapon of choice during the Rwandan genocide - the machete - was produced solely by a coffee processing company with links to a UK-based investment firm. ${ }^{48}$

But this brings me back to Yugoslavia and the question of the economic causes of the genocide. Were Belgrade economic policies and the rise of "Party oligarchies" in the various Yugoslav Republics a prime factor? Republics such as Slovenia and Croatia were exploited severely by Belgrade for their economic resources, and, Slovenia for instance, was attacked by the Yugoslav People's Army with Slobodan Milosevic at its helm. In one sense, Milosevic actions were almost premeditated. As early as 1990, Milosevic made it known that 'economic and cultural progress' would be pursued by his regime in light of the Yugoslav crisis, as he addressed a congress of the Serbian Communist Party, and that 'disintegrative forces' that poses a threat to Serbia were a serious concern. ${ }^{49}$ Milosevic was an anti-reformist and famously pursued a policy of economic nationalism to "re-start" the Serbian economy through the plundering of 'the resources of other Yugoslav Republics (in practice Slovenia which in 1989 transferred to Serbia 5.2\% of its social product, and Macedonia, which transferred $8 \%$, but not Croatia). This effort was to hasten the destruction of the former Yugoslavia. ${ }^{50}$ The transfer of wealth from the richer Republics to Serbia did not sit well with the secessionist movements that was brewing in those republics. For Belgrade, and thus Serbia, keeping the Federation together was paramount. But Serbia could not hold back the tides of session and between 1991 and 1992, Croatia, Slovenia and Bosnia-Herzegovina seceded. As Serbia's economy declined in the early 1990s and suffered from UN sanctions, Belgrade resorted to economic blockade against other rebellious republics. Thus, Belgrade's "re-start" reforms and economic plundering of the more prosperous republics and various economic blockade helped to open old wounds on nationalism and a full blown civil war in the Balkans became a television drama for western audiences as they glued to their television sets on

\footnotetext{
${ }^{48}$ See Alison Des Forges, Leave None to Tell the Story (New York: HRW, 1999) 167: 'The only local manufacturer of machetes was Rwandex Chillington, a joint venture between Plantation \& General Investments, based in the United Kingdom, and Rwandex, a coffee processing company.'

${ }^{49}$ Slobodan Milosevic, Closing Statement to the First Congress of the Socialist Party of Serbia, Belgrade, 1990, cited in Christopher Lamont, International Criminal Justice and the Politics of Compliance (Ashgate, 2010) 63.

${ }^{50}$ Michael Palairet, 'The Economic Consequences of Slobodan Milosevic' (2001) 53 Europe-Asia Studies 903 - 919, 907); see also, Susan Woodward, Socialist Unemployment: The Political Economy of Yugoslavia 1945 - 1990 (Princeton, 1995).
} 
allegations of genocide and other crimes of crimes. In this context, the economic measures undertaken by Belgrade under Milosevic deliberately inflicted destruction and initiated the physical destruction in whole and in part of the Slovenes, Croats, and Bosnians during the Balkans war.

\section{B. Calculated economic measures upon "conditions of life" (ethnic cleansing) and South Sudan}

To examine the concept of "conditions of life", and, how economic measures are calculated to bring about destruction, that, will ultimately kill the members of the group, for genocide to have a legal meaning, we must ask ourselves two basic questions. The first is, how valuable is the land that the members of the group occupy or own, and, what are the natural resources on that land (or significant part of a nation state). The second question is, to what extent are economic measures calculated so that they eventually bring about the killing and destruction of members of a group. Put another way, was the ethnic cleansing of Darfur, East Timor, Rwanda, Bosnia-Herzegovina, and those of the Rohingya in Burma as a result of natural resources and property with a high value economic impact for corporate shadowy entities (or state non-military agencies) and should they be held responsible for the crime of genocide? In all likelihood, these factors played a role, yet seemingly, they are factors, furthest away from how the crime of genocide has been constructed or even interpreted within the international justice system.

There is a provision in the ICTY Statute that covers plunder of public or private property - as violations of the laws or customs of war. ${ }^{51}$ This provision, however, does not cover the crime of genocide per the ICTY Statute. Yet, as a customary rule of international law, plundering and pillage of property is a serious and grave crime. For the purposes of clarity, I am defining public and private property to also include cultural property and heritage, as often, it is difficult to separate the economic value of public and private property

\footnotetext{
${ }^{51}$ Article 3(e). See also, Prosecutor v Delalic, Case No. IT-96-21-T, 16 November 1998, para. 591, defining plunder as: 'all forms of unlawful appropriation of property in armed conflict for which individual criminal responsibility attaches under international law, including those acts traditionally described as "pillage".' See also, William Schabas, The UN International Criminal Tribunals - The Former Yugoslavia, Rwanda and Sierra Leone (CUP, 2006) 264 - 265, citing cases such as Prosecutor v Kordic, Case No. IT-95-14/2-T, 26 February 2001, para. 352; Prosecutor v Naletilic, Case No. IT-9834-T, 31 March 2003, para. 615.
} 
from that of cultural property. Moreover, the Statutes of the ICC and the ICTY for example, refers to cultural heritage and plundering of private property in closely aligned clauses. ${ }^{52}$

One form of property with high economic value - art and artefacts is already classified as cultural heritage in need of protection under international law. ${ }^{53}$ However, cultural heritage as a form of property is only endemic to the Western world, in particular Europe. This is not so much the case for the South, where natural resources and land are their only form of property with high economic value. Thus, taken in this context, the very existence of international legal instruments that protects cultural heritage is biased against property and natural resources of countries in the South where conflicts are endemic and the crime of genocide often occur. Nevertheless, international criminal tribunals such as the ICTY have given a broad meaning to the notion of plunder, and hence, a connection to genocide. For example in Jelisic, the ICTY defined plunder as: 'fraudulent appropriation of public or private funds belonging to the enemy or the opposing party perpetrated during an armed conflict and related thereto, ${ }^{54}$ and similarly in Kunarac, the tribunal stated that plundering includes 'unjustified appropriations of property either from more than a small group of persons or from persons over an identifiable area. ${ }^{55}$ In these contexts, the ICTY has clearly identified economic plundering as a factor in war crimes. The implications of war crimes for genocide in this context is that war crimes affects the conditions of life for groups of people that are victims.

It is important to stress that while the looting of cultural property in armed conflicts is classified as a war crime, this does not mean, that it meets the legal requirements for genocide. However, what is important, is that, as a form of pillaging of the economic value of a group of people or a nation, the looting of cultural

\footnotetext{
${ }^{52}$ Article $8(2)(e)($ iv) of the ICC refers to attacks on cultural heritage, and then, immediately in the next clause (Article $8(2)(e)(v)$ to the "pillaging" of a town even when taken by assault during conflicts. See also, Article 3(d) of the ICTY stating what is arguably, cultural heritage as those 'institutions dedicated to religion, charity and education, the arts and sciences, historic monuments and works of art and science.' 53 UNESCO, Convention for the Protection of Cultural Heritage in the Event of Armed Conflict, 249 UNTS 240, 14 May 1954; The Convention Concerning the Protection of the World Cultural and Natural Heritage, 1037 UNTS 151, 16 November 1972; See eg, Roger O'Keefe, 'Protection of Cultural Property Under International Criminal Law' (2010) 13 Melbourne Journal of International Law 339; Hirad Abtahi, 'The Protection of Cultural Property in Times of Armed Conflict: The Practice of the International Criminal Tribunal for the Former Yugoslavia' (2001) 14 Harvard Human Rights Journal 1 - 32; Elisa Novic, The Concept of Cultural Genocide - An International Law Perspective (OUP, 2016). 54 Prosecutor v Jelisic, Case No. IT-95-10-T, 14 December 1999, para. 48.

55 Prosecutor v Kunarac, Case Nos. IT-96-23-T and IT-96-23/1-T, decision on motion for acquittal, 3 July 2000 , para. 16.
} 
property affects the economic conditions of life of those people. Moreover, when seen together, the looting and destruction of cultural property, or expropriation and plundering of property during armed conflicts, not only violates international law, they are 'committed as part of a genocide. ${ }^{56}$ Moreover, the tribunal in Krstic confirmed that the destruction of personal property may also facilitate the appropriate mens rea in order to make a conviction for the crime of genocide. ${ }^{57}$

Given that article 2(c) of the Genocide Convention is designed to cover a range of issues (and was a compromise clause that satisfied the various proposals during the negotiations) and that there is a connection with plundering of property or cultural heritage to genocide - the question that now remains to be settled is how best plundering of property is best attributed to genocide and hence affects the conditions of life of a group of people.

In this context, a case study is relevant. Again, given that it is only the ITCY, the ICTR and the ICC have answered questions of genocide in the present context of international law, it would be best to turn to one of those countries or groups of people, where a successful conviction of genocide was achieved to serve as a relevant case study. However, the ICC has issued an arrest warrant ${ }^{58}$ for a sitting head of State - Omar alBashir - of Sudan, and one of the charges is that of genocide. The counts of genocide against al-Bashir, reads as follows: 'genocide by killing (article 6 -a), genocide by causing serious bodily or mental harm (article 6-b) and genocide by deliberately inflicting on each target group conditions of life calculated to bring about the group's physical destruction (article 6-c). ${ }^{59}$ The latter part of the genocide charge reflects how I interpret in this paper the notion of economic genocide.

As such, the remainder of this section, turns to an analysis of the alleged ethnic cleansing in South Sudan and the Darfur region and the relation, if any, to plundering of property and other economic high value resources that resulted in the destruction of the conditions of life of Darfurians as a group of people. The

\footnotetext{
${ }^{56}$ See eg, Presbyterian Church of Sudan v Talisman Energy, Inc. 244 F. Supp.2d 289, 325 (SDNY 2003).

57 Prosecutor v Radislav Krstic, Case No. IT-98-33-A, 19 April 2004, para 141, but see footnote 247.

${ }^{58}$ Second Warrant of Arrest for Omar Hassan Ahmad Al Bashir, ICC-02/05-01/09-95, 12 July 2010.

59 Prosecutor v Al Bashir, ICC-02/05-01/09 (Pre-trial).
} 
ICTR's judgment in Akayesu can serve as a reminder of how economic genocide relates to groups of people that are, for the purposes of the genocide convention 'economic groups. ${ }^{60}$ The common denominator for economic genocide whether occurred in Rwanda, the Balkans, Sudan or Burma is the need to control territory and the management of the economic resources on those territories. Another denominator for perpetrating a crime that affect the conditions of life of the people on those territories is the design of economic policies that eventually leads to the displacement or killing of people. In other words, blame can always be shifted to the victims for deteriorating economic conditions that the perpetrator themselves experience when one considers the mob theory mentioned earlier.

Darfur in South Sudan, like many conflict zones in the world such as Rohinga in Burma, have seen a group of peoples and other ethnic minorities chased and killed from their lands. These crimes have been widely catalogued as ethnic cleansing - yet, the more sinister reason for the occurrence of those crimes lie in the high value of economic property and natural resources. ${ }^{61}$ In the case of Darfur, the conflict, was in part, due to the economic high value system of energy (and sometimes religion). In one of the early cases that signified how economic aspects of energy, and, religion, was essential in the ethnic cleansing in South Sudan, in Presbyterian Church v Talisman Energy, a US backed Christian group sued Talisman Energy for conspiring with the Government of Sudan to violate customary international law related to genocide. ${ }^{62}$ Although, this was a suit filed in a national court, its significance to the conflict and claims of ethnic cleansing, and subsequent genocide, in what is now South Sudan cannot be brushed aside. Although the Second Circuit Court of Appeal in the US explained that that it had jurisdiction for claims for genocide against individuals, ${ }^{63}$ it eventually turned down the appeal raised by the biblical men of the Sudan.

\footnotetext{
${ }^{60}$ Akayesu (n 10) para. 511.

${ }^{61}$ See eg, Luke Patey, 'Crude Days Ahead? Oil and the Resource Curse in Sudan' (2010) 109/437 African Affairs 617 639; Saskia Sassen, Expulsions - Brutality and Complexity in the Global Economy (Harvard University Press, 2014); Kevin Woods, Commercial Agriculture Expansion in Myanmar: Links to Deforestation, Conversion Timber and Land Conflicts (March 2015); Stanley Engerman and Jacob Metzer (eds), Land Rights, Ethno-Nationality, and Sovereignty in History (Routledge, 2004).

62 The Presbyterian Church of Sudan, et al v Talisman Energy Inc, and Sudan, 582 F.3d 244 (2009), 2 October 2009.

63 Ibid, p. 255. See also, Michael Kelly, Prosecuting Corporations for Genocide (OUP, 2016); Niels Beisinghoff, Corporations and Human Rights: An Analysis of ACTA Litigation against Corporations (Peter Lang, 2008); P. Sean Morris, 'Lex Internationalis: Kiobel, Empires, and the Color of Human Rights' (2015) 7 Georgetown Journal of Law \&
} 
Nevertheless, the broader question that the case raised was whether corporations can be sued for complicity in genocide, ${ }^{64}$ and, it is the belief of this writer, that, it is an unequivocally "yes", if those corporations are sued under the Genocide Convention, taking into consideration article 2 and its clauses.

Transnational corporations that invest outside of their home jurisdiction often engages the host state in a number of agreements that are beneficial to the economic output of the investing corporation. One of the claims by the plaintiffs in Presbyterian $v$ Talisman was that the defendants were knowledgeable of atrocities being committed against the plaintiffs as it caused their displacement, and, furthermore, Talisman Energy aided and abetted by the Sudanese military and exacerbated the atrocities. In this context, given that, knowledge, or mens rea, has been confirmed in cases such as Krstic and other international tribunals it would be very difficult for an international tribunal to summarily dismiss a claims based on this principle. ${ }^{65}$ Although, the Second Circuit rightly applied international criminal law principles in its decision (the suit also involved the Alien Tort Statute (ATS), and hence warrants international legal principles), it failed to analyse article 2(c) of the Genocide Convention that could substantively determine the effect upon the conditions of life of the Sudanese Christians. Given that lack of analysis, the court had no choice but to dismiss the claim given that there was no evidence to prove Talisman caused harm to the people of South Sudan. The fundamental question regarding Talisman Energy in this dispute was whether a corporation possess the qualification of "intent" to commit genocide during the civil war in the Sudan. At the national level, some courts have said that corporations can be liable for a certain intent: 'a corporation may be liable criminally for certain offences of which a specific intent may be a necessary element.. ${ }^{66}$ Thus, if corporations possess certain intent at the domestic level and can be held criminally liable for such intent does this mean, there is a difference at the international level? In fact, that is the precise situation, as corporations are generally excluded by international tribunals for violation of human rights and or aiding

\footnotetext{
Modern Critical Race Perspective 71 - 106 (discussing the fallacy of using the Alien Tort Statute as a human rights tool).

${ }^{64}$ See for example, the lower court opinion in Talisman Energy 2003, where the court argued that 'corporations may also be held liable under international law, at least for gross human rights violations' (n 56), 319.

${ }^{65}$ Krstic (n 57) para. 71.

${ }^{66}$ New York Central Railroad Co. \& Hudson River Railroad Co. v United States, 212 U.S. 481, 493 (1909).
} 
and abetting specific crimes that affects the conditions of life of ethnic groups. This was not the case prior to Genocide Convention, as tribunals such as Nurnberg found corporations liable for violating international law. ${ }^{67}$ Furthermore, the post-war criminal tribunals such as the ICTR and the ICTY have found the individuals responsibility for cultural crimes and also the plundering of property.

The question of economic genocide in the Sudan has a long and sordid history. Most of the elements that constitute genocide in general in the Sudan lie in man-made famine. Various regimes in Sudan since its independence have used economic policies that resulted in high food prices that have contributed to the genocide in the years since Sudan escaped colonial. ${ }^{68}$ The ethnic division of the Sudan between the "blacks" and the "Arabs", also along religious lines, Muslims versus Christians, fuelled the economic and power struggle for territorial control of the Sudan. While, what is now South Sudan, has, in the past, enjoyed some amount of autonomy, the deep divisions along race, religion and economic status between black and Arab Sudanese was always difficult to extinguish. Thus, economic policies (including attracting foreign investments) were always executed by those in political power. To use, the words of the Akayesu tribunal, a mob could be influenced to commit crimes for economic and territorial control. Thus, as various groups of people such as the Dinka in the Sudan were murdered over the decades since independence, ${ }^{69}$ the control for territory and the natural resources on the land was also a prime factor for mass murders that in modern times is "ethnic cleansing". Because economic policies that perpetuated the famine were no longer an option, the physical destruction that lead to the killing of black Sudanese became more prominent. This became even more pronounced since Omar al-Bashir took political power of Sudan in a 1989 coup. Thus, by 2003 , the old wounds among the various ethnic groups and along religious lines in Sudan flared up and an all-out civil war captivated the world's attention. The economic policies and the brutal civil war in Sudan under the Bashir regime eventually lead to Africa's newest nation - South Sudan. It was during the civil war

\footnotetext{
${ }^{67}$ Agreement for the Prosecution and Punishment of Major War Criminals of the European Axis, and Charter of the International Military Tribunal, 82 UNTS 280, entered into force 8 August 1945, Articles 9 - 10; United States v Krauch, 8 CCL No. 10 Trials (1952) (U.S. Mil. Trib. VI 1948).

${ }^{68}$ Hannibal Travis, 'Genocide in Sudan: The Role of Oil Exploration and the Entitlement of the Victims to Reparations' (2008) 25 Arizona Journal of International and Comparative Law $1-73,8$.

${ }^{69}$ Travis, ibid, 9, citing the 1988 massacre of some 20,000 Dinka people in the Sudan.
} 
and the eventual secession that claims under the modern scope of genocide surfaced and made Bashir a wanted man in The Hague to face the allegations of crimes of genocide.

The question then becomes - were there economic motives for the crimes of genocide by the al-Bashir regime, and if so, can these economic motives help to construct a new concept of economic genocide? I am aware of a few papers (no doubt countless others exist) - one legal, ${ }^{70}$ one economic ${ }^{71}$ and the third and fourth, social science analysis, ${ }^{72}$ that suggest that (a) there were economic motives for the genocide in Sudan, and (b) the concept of economic genocide should be considered in the legal analysis where it matters - the ICC. Writing under a different context, Nielsen has captured the mob theory for economic genocide as mooted by the Akayesu tribunal. According to Nielsen the 'economically destitute northern Arab pastoralists ${ }^{73}$ preyed on Darfur as an integral part of 'their territory' and their formation into militias ${ }^{74}$ backed by the al-Bashir regime used economic policies to create 'ethnic boundaries as economic boundaries. ${ }^{75}$ This resulted in Darfurians creating the wealth for the elite and growing inequalities: 'this contributed to ethnic tensions by leaving some economically destitute and others well off. Conflicts of an economic nature often taken on ethnic form. ${ }^{76}$ Nielsen's finding strike a tone with what this article has been advocating as the missing link on the conception of economic genocide and what is outlined in the Genocide Convention. According to Nielsen economic genocide occurred in Darfur: 'economic destruction ... has taken place. ... The term genocide as enshrined in international law seems to apply to the violence in Darfur. ... I contend that the state-sponsored attacks on the homeland of the rebel militias, the destruction of civilian economic life and food sources, and the mass displacement and expropriation of the population would constitute genocide under the UN definition. ${ }^{77}$ Although the requirements for genocide is a legal one, per the Convention, other economic studies have pointed to a link between ethnic cleansing and

\footnotetext{
70 Travis, ibid.

${ }^{71}$ Valsecchi and Olsson (n 78).

${ }^{72}$ Ahmed (n 1). See also, Erik Nielsen, 'Ethnic Boundaries and Conflict in Darfur - An Event Structure Hypothesis' (2008) 8 Ethnicities $427-462$.

${ }^{73}$ Nielsen, ibid, 435.

${ }^{74}$ Ibid, 451.

75 Ibid, 443.

76 Ibid.

77 Ibid, 456 - 457.
} 
genocide in Darfur. ${ }^{78}$ This is essential given that during genocidal trials, it is rare, if ever happen for, witnesses to be called to testify on how economic conditions, policies and motives perpetuate ethnic cleansing and thereby qualify for the crime of genocide due to the conditions of life under ethnic cleansing.

Although international criminal tribunals such as the ICTR have argued that persons can be held criminally liable for genocide if they aid and abet such crimes but not "specific intent" to commit genocide ${ }^{79}$ suggests that international tribunals are willing to consider how economic genocide are committed. For the purposes of customary international law it is important to establish that aiding and abetting requires some amount of knowledge for the application of the mens rea standard. ${ }^{80}$ The mens rea standard of knowledge has also been confirmed in Akayesu, ${ }^{81}$ Tadic $^{82}$ Musema $^{83}$ and Miltutinovic. ${ }^{84}$ Given this trend on the application of the knowledge standard in international law for aiding and abetting, and, in cases such as Talisman Energy, where the corporation admitted to knowingly of crimes against ethnic groups in Sudan, the same standard can be applied for the economic crime of genocide. The crime of genocide in international criminal law is an intersection between moving and still parts of the international legal system. On the one hand, the crime of genocide is a crime enforced under conventions and other treaties and therefore requires those treaties to be also interpreted in light of customary international law. ${ }^{85}$ Therefore, this also makes the crime of genocide a still object in the international legal system in that it is a recognisable crime in customary international law. In this regard, the presence of customary international law does not affect the application of international legal rules to the crimes of genocide under a convention given that the contents of customary international law are identical to those in treaties. This was confirmed

\footnotetext{
78 See eg., Michele Valsecchi and Ola Olsson, 'Quantifying Ethnic Cleansing: An Application to Darfur' (2010), SWOPEC Working Paper No.479; Philip Verwimp, 'An Economic Profile of Peasant Perpetrators of Genocide: Micro-level Evidence from Rwanda' (2005) 77 Journal of Development Economics 297 - 323; Jose Montalvo and Marta ReynalQuerol, 'Discrete Polarisation with an Application to the Determinants of Genocides' (2008) 118 The Economic Journal $1835-1865$.

${ }^{79}$ Akayesu (n 10) para. 545.

${ }^{80}$ Krstic (n 57) para. 71; Prosecutor v Furundziha, Case No. IT-95-17/1-T, 10 December 1998, para. 249; Muvunyi v Prosecutor, Case No. ICTR-2000-55A-A, 29 August 2008, para. 79.

${ }^{81}$ Akayesu (n 10) para. 545.

82 Prosecutor v Tadic, Case No. IT-94-1-T, 7 May 1997, para. 692.

${ }^{83}$ Prosecutor v Musema, Case No. ICTR-96-13-T, 27 January 2000, para.180.

${ }^{84}$ Prosecutor v Multinovic, et al, Case No. IT-05-87-T, vol. 3, 26 February 2009, para. 281.

${ }^{85}$ Vienna Convention on the Law of Treaties (1969), 1155 UNTS 331, Article 31(3).
} 
in Nicaragua $v$ the United States where the ICJ explained that the rules contained in a treaty have no effect on the applicability of customary international law. ${ }^{86}$

The modern tribunals such as the ICC are now tasked to bring both standard treaty interpretations and also the customary international law of civilized states into a diagnostic form not only to punish genocide as per the Convention, but also to address economic genocide. In this regard, there is an obligation on the ICC, for example, to address economic genocide in light of customary international law and the interpretation of conventions as crime, whereas, the spill over intent affect the conditions of life where killing and the crime of genocide occurred. By addressing the spill over intent to commit genocide the ICC can reasonably infer that article 25(3)(c) of its statute necessarily incorporates a crime of economic genocide from which reasonable knowledge by the aiders and abettors can be found guilty. Article 25(3)(c) of the Rome Statute remains controversial, yet, there is a ray of hope in its formulation. That provision can be viewed in a liberal fashion, where those complicit in aiding and abetting genocide and have direct knowledge of such crimes, as in Talisman Energy, are taken into account based not on their specific intent to commit genocide, but rather, their spill over intent in the crime of genocide. In this regard article 25(3)(c) suggests the need for a liberal deduction of spill over intent. Talisman Energy did concede that it engaged with government military operations in Sudan as part of a buffer zone strategy to protect its facilities, ${ }^{87}$ but, its actions were not to be viewed as violations under international law. According to Talisman, the forcible displacing of civilian populations was not unlawful. ${ }^{88}$ This admission begs the question, was Talisman Energy a full perpetrator of the crimes of crimes in the Sudan, or, was it simply aiding and abetting the Government of Sudan to protect its investments and profits?

\footnotetext{
${ }^{86}$ Case Concerning Military and Paramilitary Activities in and Against Nicaragua (Nicaragua v United States), Merits, ICJ Reports 1986, p.14, 27 June 1986, para. 175: 'even if a treaty norm and a customary norm ... were to have exactly the same content, this would not be a reason for the Court to take the view that the operation of the treaty process must necessarily deprive the customary norm of its separate applicability.'

${ }^{87}$ Talisman Energy (2009) (n 62), 263: 'The oil facilities came under frequent rebel attack and oil workers were killed during the relevant time. Safe operation pf the oil facilities therefore required tightened security; and displacing civilians from an area within the security ring road was not itself unlawful.'

88 ibid. But see Akayesu (n 10) para 523: 'it is possible to deduce the genocidal intent inherent in a particular act charged from the context of the perpetration of other culpable acts systemically directed against that same group, whether these acts were committed by the same offender or by others.'
} 
The Darfur genocide is not unique. The international community have seen similar atrocities in Rwanda, Cambodia, Bosnia, and recently in Myanmar. Although some attempts have been made to paint the Darfur genocide as ambiguous ${ }^{89}$ - such characterisation only mask the failure of the international community to prevent the Darfur genocide. As the discussion in this article demonstrate, the Darfur genocide fit all the characteristics of economic genocide and is in line with the definition of the genocide under the Convention. The recognition of economic genocide is the root cause of the crimes of crimes that face the international community, yet, it is a phrase, that eludes the tongues of men that shapes international criminal law and those who dispense "justice" from the tribunals and courts where the convicts for genocide are mostly African.

\section{Conclusion}

The international legal framework for the crime of genocide is still a work in progress. This is so, because, despite the qualifications for the crime of genocide as set out in article 2 of the Convention, a number of other qualifications that aid and abet genocide are missing. One such qualification is economic genocide as set out in this paper. The ICTY and ICTR have flirted with various composites of economic value, such as plundering of property, and, the looting and destruction of cultural heritage, but have come up short of classifying such crimes as economic genocide. Moreover, with the existence of the ICC as a permanent court with jurisdiction over genocide, there is little effort to call upon economic experts as witnesses to quantify genocide through economic policies and motives that resulted in the displacement, killings and destruction of peoples and thereby their conditions of life. By invoking the economic contexts in which genocide is perpetrated and adversely affected the conditions of life of peoples have proven that the crime of genocide is the root cause of the crimes of crimes, yet, rhetorically and legally, the economic conditions that leads to genocide is being excluded from the narrative in international criminal law.

\footnotetext{
${ }^{89}$ Gerard Prunier, Darfur: The Ambiguous Genocide (Cornell University Press, 2005).
} 